Article

\title{
Sustainable Purchasing Patterns and Consumer Responsiveness to Sustainability Marketing Messages
}

\author{
Randi Kronthal-Sacco *, Tracy Van Holt, Ulrich Atz, Tensie Whelan \\ New York University, Stern School of Business, 44 West 4th Street, New York, \\ NY 10012, USA \\ * Correspondence: Randi Kronthal-Sacco, Email: rkrontha@stern.nyu.edu; \\ Tel.: +1-212-998-0048.
}

\begin{abstract}
Background: Retailers and brand managers may be reticent to introduce products that are marketed as sustainable because prior research identifies a discrepancy between what consumers say they intend to purchase (via survey) and what they actually do at retail (via purchases). This research shows that despite this gap, products that have sustainable claims on their package are outperforming growth of conventional products in respective categories.
\end{abstract}

Methods: We conducted a large-scale study of U.S. consumer purchases using IRI retail barcode data from 2013 to 2018, analyzing 36 consumer packaged goods (CPG) categories, representing $41 \%$ of total CPG dollar volume. We conducted detailed analyses of marketing messages from a subset of categories representing both high and low sustainabilitymarketed share development.

Results: We calculated that $\sim 50 \%$ of the growth in the in-sample CPG market came from sustainability-marketed products. These products accounted for $17 \%$ share of market (\$) in 2018, up from 14\% in 2013. Our detailed marketing-message analysis in five categories found:

- The most commonly found sustainability messages were category specific. Organic was the most dominant.

\section{G Open Access}

Received: 07 November 2019

Accepted: 14 March 2020

Published: 25 March 2020

Copyright (C) 2020 by the author(s). Licensee Hapres, London, United Kingdom. This is an open access article distributed under the terms and conditions

- Legacy (mainstream) brands that adopted sustainability messages contributed more to share increases of sustainability-marketed products than smaller, non-legacy brands.

- Higher efficacy products with sustainability claims had lower market share than lower efficacy products. However, in a study of one product category, we found that sustainability-marketed products performed best when accompanied by explicit efficacy claims.

- In four of the five categories examined, third-party certified sustainability-marketed products significantly outgrew sustainable products that had sustainable messaging, but no third-party certification.

of Creative Commons Attribution 4.0 International License. 
KEYWORDS: consumer packaged goods; sustainable marketing; sustainable consumption; sustainable purchase behavior; messaging; purchase data

\section{INTRODUCTION}

We present a timely, multi-category study of U.S. consumer purchasing behavior of sustainability-marketed products in consumer packaged goods (CPG). CPG is a useful category to gauge consumer buying patterns overall as consumers frequently buy packaged food and personal care products. The purchase data (barcoded data) is available from retailers and aggregated by Information Resources, Incorporated (IRI). We coded and compared various marketing messages (functional claims, sustainability claims, third-party certifications, and brand) in select categories representing both high and low shares of sustainabilitymarketed products. This research examined actual purchases, not consumer purchase intent. We contribute to the literature by quantifying the changes in actual consumer purchases of sustainability-marketed products on an exceptionally large scale.

Our overall objective was to understand consumer-purchasing behavior of sustainability-marketed consumer packaged goods (CPG). We asked the following questions:

1. Have purchases of sustainability-marketed CPG products increased from 2013 to 2018 ?

2. Are there specific CPG product categories where the purchases of sustainability-marketed products outperformed conventionallymarketed products?

3. Which sustainability-marketing messages (functional claims, sustainability claims, third-party certifications, and brands) were associated with growth of sustainability-marketed products?

\section{Growth of Sustainability-Marketed Products and Categories}

Businesses today need to rethink how they are producing and sourcing products so Earth can remain within its planetary boundaries-the safe operating space for humanity [1,2]. At the same time, companies need to deliver growth by providing products that consumers demand. If sustainability-marketed products are a driver of growth, then this type of information can help make the business case for brands and retailers to invest in sustainable products. Academics argue that changes in business practices are crucial to achieve sustainable development goals and environmental change [3]. Sustainability-marketed products are topics of interest to companies [4]. Consumers consistently report positive attitudes towards sustainable products, and a willingness to pay more for such products [5]. Companies should benefit from marketing a product as sustainable; however, past research has shown that consumer intent does 
not always translate into actual purchases at the checkout counter [6,7]. If consumers acted on their intentions, then businesses might find more reasons to invest in sustainability, and communicate this in product messaging. Academic research shows that there is a gap between consumers' stated intentions (i.e., their willingness to purchase sustainable products), and actual purchases of sustainability-marketed products [7-11]. Academics report on this gap in the literature so extensively that it is common knowledge in consumer and market research [12]. However, with the US public increasingly concerned about environmental changes [13], and discussing sustainable consumption [14], we should expect a change in consumer purchasing behavior of sustainability-marketed products in the US.

What we currently know about consumer purchasing behavior of sustainability-marketed products relies on small-scale studies. These include either controlled behavioral studies that evaluated, for example, rating product characteristics in decision-making [15-19] or single category in-market data that examined, for example, whether purchases were driven by quality or sustainability messaging in a single country, and category (e.g., organic coffee in Sweden) [20]. One exception is the widely cited 2005 United Nations Environmental Program study that synthesized known research on sustainability-marketed product purchases across the globe. They found that while $40 \%$ of the consumers analyzed $(N=5300)$ were willing to purchase "green" products, only $4 \%$ actually did [21]. We lack timely, academic, large-scale, purchase data on sustainabilitymarketed product sales. By large-scale, we are referring to data across multiple categories and marketing messages across large markets (e.g., the US). The consumer market for sustainable goods may have evolved significantly since 2005. We focused on actual in-market data because survey instruments focusing on reported purchasing intentions (i.e., perceptions about purchase intent) show that consumers often provide socially-acceptable responses (overestimating their intent to make ethical purchases) [7].

\section{Sustainability Messaging}

Companies use on-package claims to market the sustainability attributes of their products. Research has shown that consumers considered on-package messages when deciding what to buy [22]. Research on consumer perceptions may help us predict which categories of sustainability-marketed products we might expect to have a relatively higher market share. Studies have shown that consumers infer trade-offs between sustainable attributes and other product attributes, such as functional performance or value [15,23,24]. In a study that provided different scenarios of product attributes, Luchs et al. (2017) found that consumers reportedly were unwilling to trade functional product attributes like strength and efficacy for positive ethical attributes [15]. This means that if consumers were faced with purchasing a sustainability- 
marketed laundry detergent product, and one that was not, they would likely choose the product that was not associated with the sustainability claim, all else being equal. We may therefore expect to find lower market share of sustainability-marketed products in functional categories (those where efficacy or high functionality qualities are key product attributes), such as cleaners, deodorant and toothpaste, and trash bags. In another study, students were given a set of products that were marketed as sustainable, and they included ratings of other product attributes, e.g., strength, function, and aesthetics. Participants rated their likelihood to purchase the product. The study found that when products included explicit cues about strength or efficacy, these attenuated the perceived sustainability trade-off [16]. We tested, in one category, whether sustainability-marketed messages, combined with performance messages, made a difference in market share.

We also tested whether there was higher market share for categories with third-party certifications, which can engender greater consumer trust than self-promoted claims [25]. Researchers have shown that consumers have a good understanding of third-party certified labels such as Fair Trade, Organic, and Rainforest Alliance, for example [26,22]. Also, the sustainability messaging performs better when aligned with product category, as demonstrated by Bodur et al. (2014), who found that aligned claims improved brand perception. For example, made with natural and local ingredients in the cough cold category would fare better than a child labor free claim [17]. We also examined if there was a dominant type of sustainability claim (e.g., organic, sustainably sourced) among select categories.

Another dominant factor in explaining consumer purchasing decisions is brand. Research experiments have shown that not only are people more likely to select a product associated with a brand, but they also make these decisions quicker [27,28]. Indeed, there has been interest in large legacy vs niche brand [29]. Building on this work, we tested whether brands (large legacy vs niche brand) explained differences in market share.

\section{METHODS}

\section{Data and Category Sampling Framework}

To answer our research questions, we used in-market IRI point of sale (POS) data in measured channels for each product (all estimates and analyses in this paper based on Information Resources, Inc. data are by the author and not by Information Resources, Inc). A product is a unique code that includes all package and flavor varieties (SKUs) such as, 6 oz., 18 oz., or floral vs fresh breeze. This is because the sustainability labels were uniform at the SKU level (hereafter referred to as a product). We analyzed data from 2013 to 2018 in all measured channels, i.e., food, drugs, mass merchandisers (e.g., Walmart), military, convenience, club, and dollar stores. Our category sampling reflected a large fraction of the total CPG 
market excluding alcohol and tobacco. We included 36 product categories (41\% of the market in dollar volume in 2018), and we refer to this as the in-sample CPG market in this paper. We started by selecting CPG categories that represented the largest dollar volume in 2018. The largest categories excluded from edibles were bottled water, non-chocolate candy, and ice cream. From non-edibles, cold/allergy tablets, internal analgesics, and pet supplies were excluded. We then included smaller categories to make sure that we represented the major categories in CPG. For example, frozen dinner entrees were included to represent frozen foods even though they were not the highest dollar share in 2018. This category sampling, we argue, is representative of the total CPG market. We did a prior analysis with expert inputs for mean and standard deviation, so that we would achieve a margin of error of \pm 1 percentage point (which we did) for the share of sustainability-marketed products. While this was not a true random sample, our procedure provided the optimal tradeoff between making the analysis of inspecting products feasible, and representing key categories in the total CPG market such as food and beverage, personal care, laundry, snacks, pet food, paper products, and skincare.

We considered the following categories high performance: trash bags, laundry care, sanitary protection, deodorant, diapers, laundry detergent, and floor cleaner. All other categories were classified as either low performance, not applicable (edibles) or abnormalities (paper products). For the 36 selected categories, there was virtually no sampling uncertainty because we observed the product population in all IRI measured retail channels. We excluded alcohol and tobacco as products because they have distinct consumer health and safety concerns. Within those 36 categories, we examined 71,283 products in 2018 for sustainability claims. We only analyzed claims for products with a dollar share above 0.00 .

\section{Sustainability Claims in Product Marketing}

To assess whether a product was marketed as sustainable, we examined the 2018 package for each of the in-sample products. The 2018 package labels were taken as proxies for 2013 packages. This includes two potential confounding cases: (1) If a product lost all sustainable claims (that is, the product had a sustainable message in 2013 but not 2018), the 2013 data point would be miscoded as non-sustainable. We estimate that this case is extremely rare and likely absent. (2) If a product gained a sustainable claim (that is, the product had no sustainable message in 2013 but was marketed as sustainable in 2018), the 2013 data point would have been coded as sustainable by default because packaging from 2013 was not available. In this case, the growth rate of sustainable messaging would be underestimated. There were four coders: an undergraduate student, two graduate students and the lead author. We minimized errors in coding in the following ways: (1) developed a codebook that identified which labels were considered sustainable per selected category; (2) coded whether the sustainable-marketing label was present or absent; and (3) a 
second coder verified the results. This resulted in a 97 percent agreement among coders. We focused on whether the marketing of a product as sustainable would drive purchases. We did not assess if products marketed as sustainable were, in fact, sustainable. Each product was categorized as sustainability-marketed or conventionally-marketed. For the purposes of this study, we defined "sustainability" as influencing or potentially influencing the health and/or welfare of humans, animals, or the environment (see criteria in Table 1). A product was considered marketed as sustainable if it included third-party certifications about sustainability (environmental and/or social) issues such as USDA organic, Forest Stewardship Council, Rainforest Alliance, and Fair Trade). Certain company sustainability claims and/or messages on the package were also included. The sustainability-marketed classifications fell into two categories: (1) positive characteristics, e.g., sustainably sourced, organic, with organic ingredients, biodegradable, eco, local, grass-fed, compostable, animal cruelty-free, or compostable (we focused solely on the product itself and not the recyclability of the packaging except where packaging was core to the delivery, e.g., compostable k-cups), etc., or (2) undesirable traits, e.g., non-GMO, BPA free, toxin free, growth hormone free, antibiotic free, paraben free (Table 1).

Table 1. Category-specific sustainability claims and excluded claims with their respective justifications. They followed the general exclusions and inclusions in the table footer.

\begin{tabular}{|c|c|c|c|}
\hline Category & $\begin{array}{l}\text { Examples of sustainable } \\
\text { messeges }\end{array}$ & Justification & Claims not included \\
\hline Bottled Juices & BPA Free, Cruelty Free & $\begin{array}{l}\text { Human health, No animal } \\
\text { testing }\end{array}$ & \\
\hline \multicolumn{4}{|l|}{ Carbonated Beverages } \\
\hline Chocolate Candy & $\begin{array}{l}\text { Rainforest Alliance, Fair } \\
\text { Trade }\end{array}$ & & \\
\hline $\begin{array}{l}\text { Cleaners-Laundry } \\
\text { Detergent, Laundry Care, } \\
\text { Dish Detergent, Household } \\
\text { Cleaner, Floor Cleaners }\end{array}$ & $\begin{array}{l}\text { No chemicals, } 100 \% \text { Natural, } \\
\text { Plant-based, Sustainable } \\
\text { Forestry Certified }\end{array}$ & $\begin{array}{l}\text { Human health, Solvents bad } \\
\text { for the environment ( } 1.4 \\
\text { Dioxane) }\end{array}$ & $\begin{array}{l}\text { Dish detergent specific-no } \\
\text { phosphates (government } \\
\text { requirement) }\end{array}$ \\
\hline Coffee & $\begin{array}{l}\text { Compostable Single-cups, } \\
\text { Rainforest Alliance, Fair } \\
\text { Trade }\end{array}$ & & Single-Origin \\
\hline Dairy—Milk, Cheese, Yogurt & $\begin{array}{l}\text { Local, Hormone-Free, Grass- } \\
\text { fed, Antibiotic Free }\end{array}$ & $\begin{array}{l}\text { Human health for hormone, } \\
\text { antibiotics, and grass-fed. } \\
\text { Grass-fed perceived better for } \\
\text { planet. }\end{array}$ & $\begin{array}{l}\text { Plant based dairy (e.g., soy } \\
\text { milk) }\end{array}$ \\
\hline Deodorant, Toothpaste & $\begin{array}{l}\text { No Aluminum, No Phthalates, } \\
\text { Animal cruelty free, No } \\
\text { Paraben }\end{array}$ & $\begin{array}{l}\text { Human health reasons for } \\
\text { aluminum, phthalates and } \\
\text { paraben, No animal testing }\end{array}$ & \\
\hline
\end{tabular}


Table 1. Cont.

\begin{tabular}{|c|c|c|c|}
\hline Category & $\begin{array}{l}\text { Examples of sustainable } \\
\text { messeges }\end{array}$ & Justification & Claims not included \\
\hline Energy Drinks & & & $\begin{array}{l}\text { Plant-based, Alternative } \\
\text { sugars }\end{array}$ \\
\hline Frozen Dinner Entrees & $\begin{array}{l}\text { Vegan, Plant-based, } \\
\text { Phosphate-free shrimp }\end{array}$ & $\begin{array}{l}\text { Phosphate causes nutrient } \\
\text { pollution in water }\end{array}$ & \\
\hline $\begin{array}{l}\text { Grains - Fresh Bread, Cereal, } \\
\text { Cookies, Crackers }\end{array}$ & & & Natural \\
\hline $\begin{array}{l}\text { Paper-Paper Towels, } \\
\text { Sanitary Napkins, s and } \\
\text { Plates, Diapers, Facial Tissue, } \\
\text { Toilet Tissue }\end{array}$ & $\begin{array}{l}\text { FSC, SFI, Plant-based fibers, } \\
\text { Compostable, BPA Free } \\
\text { (Plates), No polystyrene foam, } \\
\text { Recyclable }\end{array}$ & & BPA Free (Cups) \\
\hline Pet-Treats, Food & $\begin{array}{l}\text { BPA Free, Dolphin Safe, No } \\
\text { hormones, Free-range } \\
\text { chicken, Grass-fed beef }\end{array}$ & $\begin{array}{l}\text { Grass-fed perceived better for } \\
\text { planet. }\end{array}$ & No-fillers \\
\hline Salty Snacks & & & natural \\
\hline Skin Care, Cosmetics & $\begin{array}{l}\text { No Phthalates, Animal cruelty } \\
\text { free }\end{array}$ & Human health & Natural ingredients \\
\hline Soap & & & Natural ingredients \\
\hline Soup & $\begin{array}{l}\text { BPA Free, Green Certified, } \\
\text { Grass-fed }\end{array}$ & $\begin{array}{l}\text { Human health, Grass-fed } \\
\text { perceived better for planet. }\end{array}$ & \\
\hline $\begin{array}{l}\text { Supplements-Weight } \\
\text { Control, Vitamins, Food and } \\
\text { Trash Bags }\end{array}$ & $\begin{array}{l}\text { Grass-fed, Plant-based, } \\
\text { Compostable }\end{array}$ & $\begin{array}{l}\text { Grass-fed perceived better for } \\
\text { planet. }\end{array}$ & \\
\hline
\end{tabular}

Exclusions: Often a product will have multiple claims. We did not consider the following types of claims as sustainable, when they appeared as the sole claim: Kosher, Gluten-Free, No artificial ingredients, No preservatives, Packaging (unless it was critical to the product, e.g., K-cups, plastic bags).

Inclusions: Organic, With-organic ingredients, Non-GMO, Third party certifications, ESG certifications, Sustainability codes like "eco-“, BPA Free, Biodegradable, Compostable, No parabens.

Omitted non-edible categories: Cigarettes, Smoking Accessories, Cigars, Smokeless Tobacco.

Omitted edible categories: Beer/Alcohol/Cider, Wine, Spirits/Liquor.

The following claims were not sufficient to classify a product as sustainable: natural, kosher, gluten-free, no artificial ingredients, or no preservatives. Cause-related marketing claims, e.g., claims that a certain percentage of sales would be donated to an environmental or social cause, were also excluded. Simple ingredients and/or a clean label were not coded as sustainable unless the ingredients themselves were sustainable. For example, peanut butter with palm oil and peanuts (simple ingredients) was not considered sustainability-marketed unless the manufacturer used sustainable palm oil. Purpose-driven brands such as Dove were excluded because this concept is relatively new, and difficult to code since brands generally market their purpose through broad advertising campaigns 
rather than on-pack claims. In addition, a purpose driven brand in and of itself, may or may not be sustainable.

We excluded private label products. This is because the IRI data aggregates all private label from multiple retailers to one datapoint in each category, and we cannot distinguish sustainability-marketed from conventionally-marketed products. For example, a Walgreens store-brand product $\mathrm{x}$ would be aggregated with Whole Food's store-brand product $\mathrm{y}$. We would lose any additional information about that product, where it came from, and how that might relate to each store's sustainability claims. To be conservative, we designated all private label products as conventionally-marketed with the exception of some organic private label food that was not aggregated.

We designated a product as sustainable based solely on its on-pack claims, rather than considering other marketing efforts. For in-person purchases, on-pack claims were the most reliable indicator of consumers' perception that a product is sustainability-marketed, as they are the only type of marketing message that has the potential to be viewed by all consumers. Other forms of advertising are targeted to consumer segments based on the audience of the advertisement (e.g., online, television, etc.), and do not necessarily reach the entire consumer market.

\section{Analysis of Product Sales}

Trends in purchasing behavior across product categories. For both questions 1 and 2 we used the in-sample POS data for each product to calculate and aggregate dollar sales (total volume) and dollar share (as percent of the category) of the product's respective category for each year from 2013 to 2018. We also calculated the projected growth of sustainability-marketed products for the following five years with a simple linear regression and assuming a linear trend. Moreover, we calculated the five-year compound annual growth rate (CAGR) for all products with sustainability claims, for conventionally-marketed products, and for the total market extrapolated from our sample. As we were dealing with a category sample of 36 categories ( $41 \%$ of total dollar sales volume of the CPG market), we produced uncertainty estimates for the total CPG market dollar sales volume of sustainability-marketed products, and total CPG market dollar share. These estimates were expressed as a margin of error, calculated with a standard 95\% confidence interval around the mean, weighted by volume, and corrected for a finite population size.

To answer question 2, in addition to the analysis described above, we calculated and compared the dollar amount of sales of sustainabilitymarketed products for 36 categories as a share of the category's total sales volume. To understand how the market share differed across categories, we grouped the categories ranging between below 5\% and above $18 \%$ producing three roughly equal bin widths, with each bin representing between ten and 15 product categories. We labelled the bins as largely 
food products, food and personal care products, and functional products and indulgence foods, respectively.

Marketing messages associated with product sales growth. To answer question 3, we employed four additional analyses of sales growth in selected categories of low ( $5 \%$ or less) and high ( $18 \%$ or more) market share of sustainability-marketed products. We classified laundry detergent, sanitary products, and chocolate as low market share. Yogurt and coffee were classified as high market share. We then compared sales growth conditional on sustainability claims, third-party certifications, (legacy) brands, and functional performance claims.

To do so, we first tested whether similar messages (e.g., organic) explained sustainability-marketed purchases in both low and high market-share categories. We analyzed by type of messaging claim the share of average annual dollar sales of sustainability-marketed products as well as the share of 2013-2018 growth of sustainability-marketed products. Second, we extended our coding of sustainability claims to list every third-party certification per product (e.g., certified USDA organic). We then compared whether third-party certification claims (or not) were associated with differences in market share as before. Third, to understand the influence of brand messaging, we examined whether large, legacy brands ( $>5 \%$ market share in a category, e.g., Tide) that adopted sustainability messages influenced growth of the sustainability share in its respective category. Here, we first produced a total and average volume sales from 2013 and 2018. This allowed us to control for ephemeral products (e.g., some brands stock their products only in certain years) because our analysis featured specific brands from major businesses and small subgroups of niche marketing claims. Fourth, we analyzed the role of functional performance messaging in laundry detergent (i.e., in a single category only). This is because qualities like strength and efficacy have been shown to be important to consumers for characteristic highfunctional product categories [15,29]. To assess whether the inclusion of a functional performance claim was associated with growth, we tested whether a functional performance claim (e.g., fights tough stains or stain fighting enzymes) on the front panel was associated with stronger sales growth. To do this we compared the market share of laundry products that contained only sustainability claims to those that contained both sustainability claims and performance claims and created a ranking.

Finally, we performed a series of robustness checks, quality assurance, and analyses to rule out other potential explanations. A typical check would compare and reconcile different aggregate statistics for total sales, for example. Moreover, we investigated if the growth of newly introduced products, i.e., those with zero sales in 2013 or after but not 2018, differed for sustainable and non-sustainable products. Many analytical decisions were guided by detailed knowledge of the CPG consumer market to rule out idiosyncratic effects. 


\section{RESULTS AND FINDINGS}

\section{Substantial Growth in Sustainability-Marketed Products}

Sustainability-marketed products grew from $14.3 \%$ in dollar sales of the CPG market (for the 36 categories analyzed) in 2013 to 16.6\% in 2018. For the total CPG market, in terms of dollar sales growth, this translates to an increase from $\$ 88$ billion in 2013 to $\$ 114$ billion in $2018(+29 \%)$ of sustainability-marketed products, and a projected growth of $\$ 140$ billion by 2023 (Figure 1). We arrived at this result by treating the $16.6 \%$ share as the best, unbiased estimate of the total CPG market (100\% of dollar sales) with a margin of error (MoE) of 1.4 percentage points. We are confident that the population value (the total CPG market share for sustainabilitymarketed products) was within the boundaries of $15.3 \%$ and $18.1 \%$ or between $\$ 104$ billion and $\$ 122$ billion in 2018. Overall, sustainabilitymarketed products grew 5.6 times faster than their conventionallymarketed counterparts and 3.3 times faster than the total CPG market as a whole (5-year CAGR) from 2013 to 2018 (Figure 2). Moreover, in three categories where conventional product sales volume was in decline, diapers, soup, and milk, the sustainability-marketed products saw both dollar volume growth, and share growth (Figure 2).

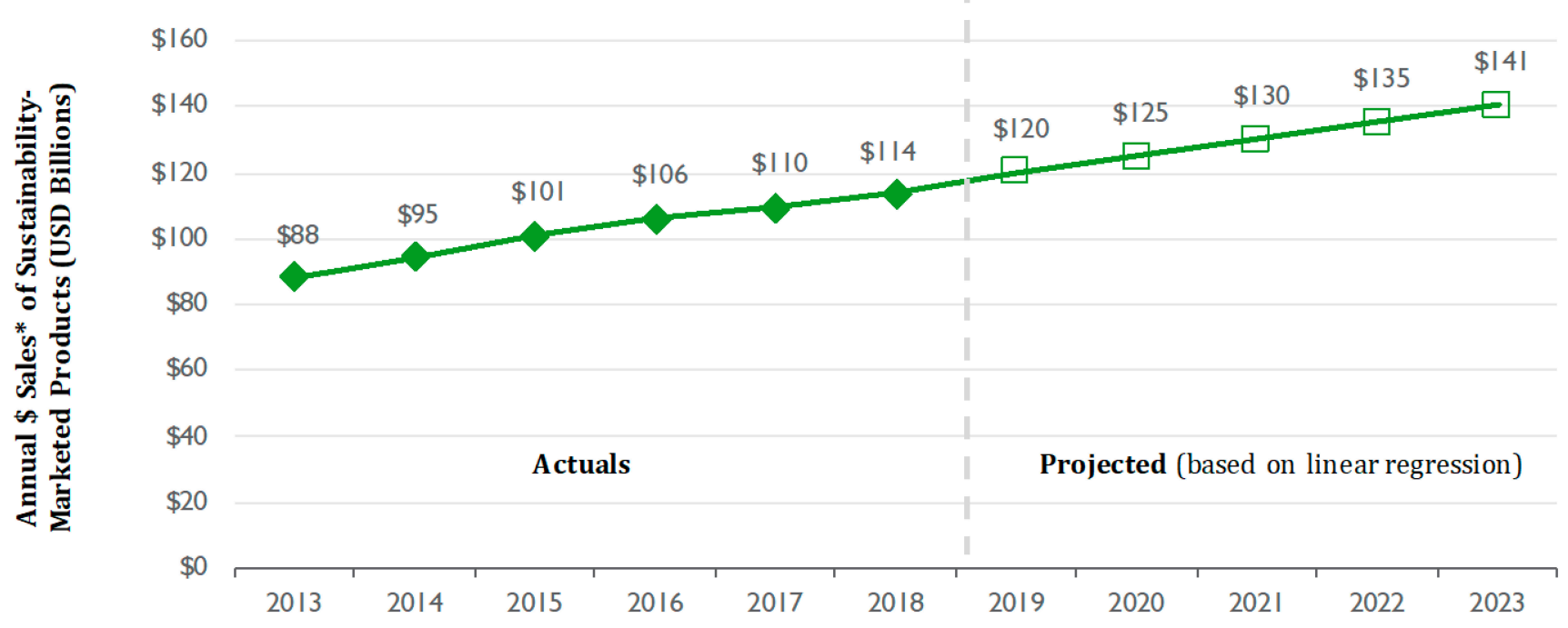

Figure 1. Across all categories, total CPG market, sustainability-marketed products delivered $\$ 113.9 \mathrm{~B}$ in sales in $2018,+29 \%$ vs 2013 and are expected to grow to $\$ 140.5 \mathrm{~B}$ by 2023 . ${ }^{*}$ The total CPG market value of sustainability-marketed products is estimated with a margin of error of \pm 1.4 percentage points, based on the actual sales of 36 product categories, representing approximately $41 \%$ of the total market in measured channels. 


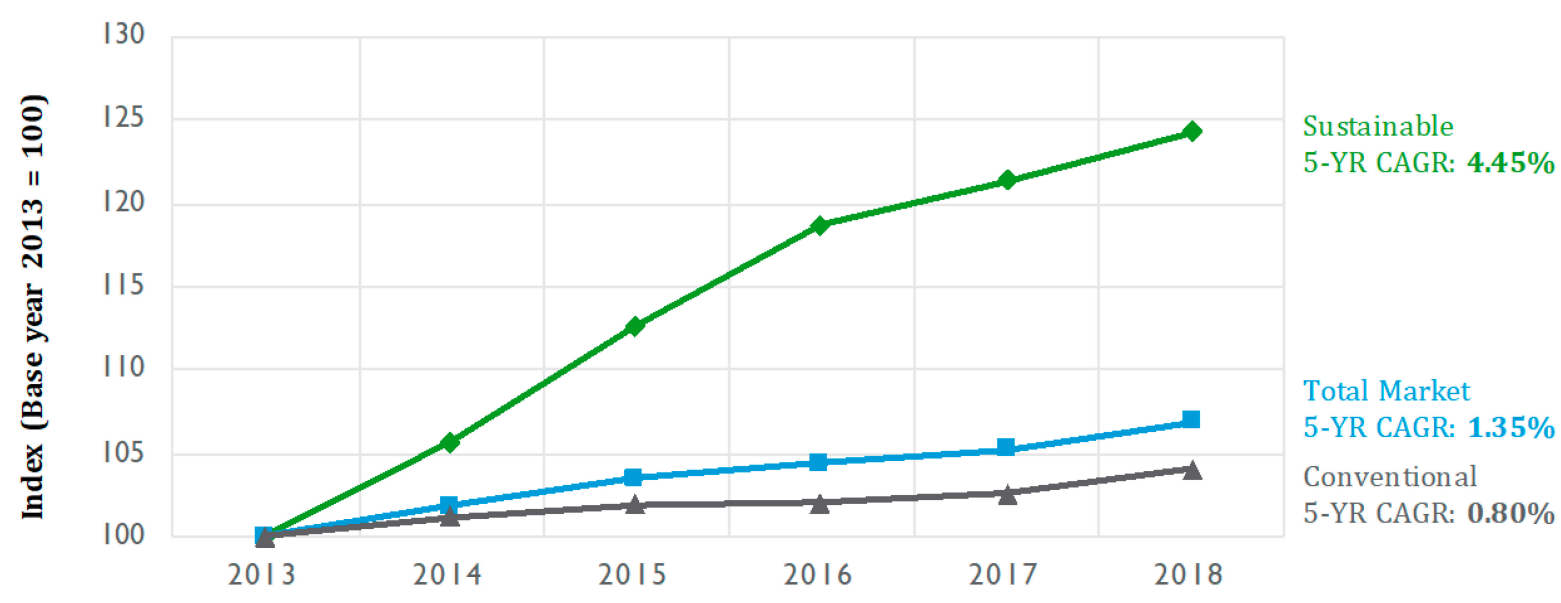

Figure 2. Sustainability-marketed products grew 5.6× faster than conventionally-marketed products, and $3.3 \times$ faster than the total CPG market.

Most importantly, we found that sustainability-marketed products were moving beyond niche positioning. While sustainability-marketed products only accounted for $16.6 \%( \pm 1.4)$, it contributed $50.1 \%$ of CPG growth from 2013 to 2018 (Figure 3) Current market share of sustainability-marketed products by category ranged from close to zero for food \& trash bags and laundry care to more than $70 \%$ for toilet tissue and yogurt.

\$ Share of Market (2018)

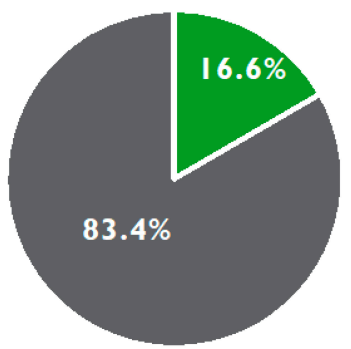

Conventional products
Sustainabilitymarketed products
\$ Share of Market Growth (2013-18)

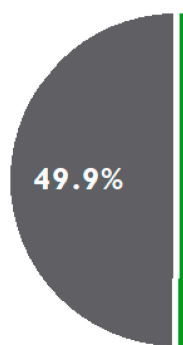

Conventional products

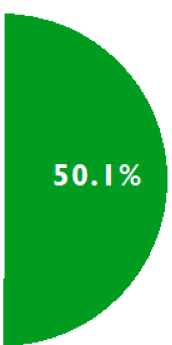

Sustainabilitymarketed products

Figure 3. Sustainability-marketed products delivered more than half of the market growth despite holding only $16.6 \%$ of the market.

\section{Functional Performance Products and Claims}

The highest share of sustainability-marketed products within a category came from food products, the second-highest share came from both food and personal care categories, and the lowest share came from functional products and indulgence foods (Figure 4). Even in these low share categories, sustainability-marketed products outperformed the market. Trash bags and laundry care, which had less than 5\% market share, for example, were high-functional, whereas many of the food products that were in the greater than $18 \%$ share were not. The overall pattern was clear: for the seven high performance products we found six 
of them in the low share group and one in the middle group, whereas for the rest (29 categories) they spread equally among the three groups. A formal chi-squared test was statistically significant at the five-percent level ( $p$-value $=0.016$ ) and so was Fisher's exact test as well as Pearson's correlation coefficient.

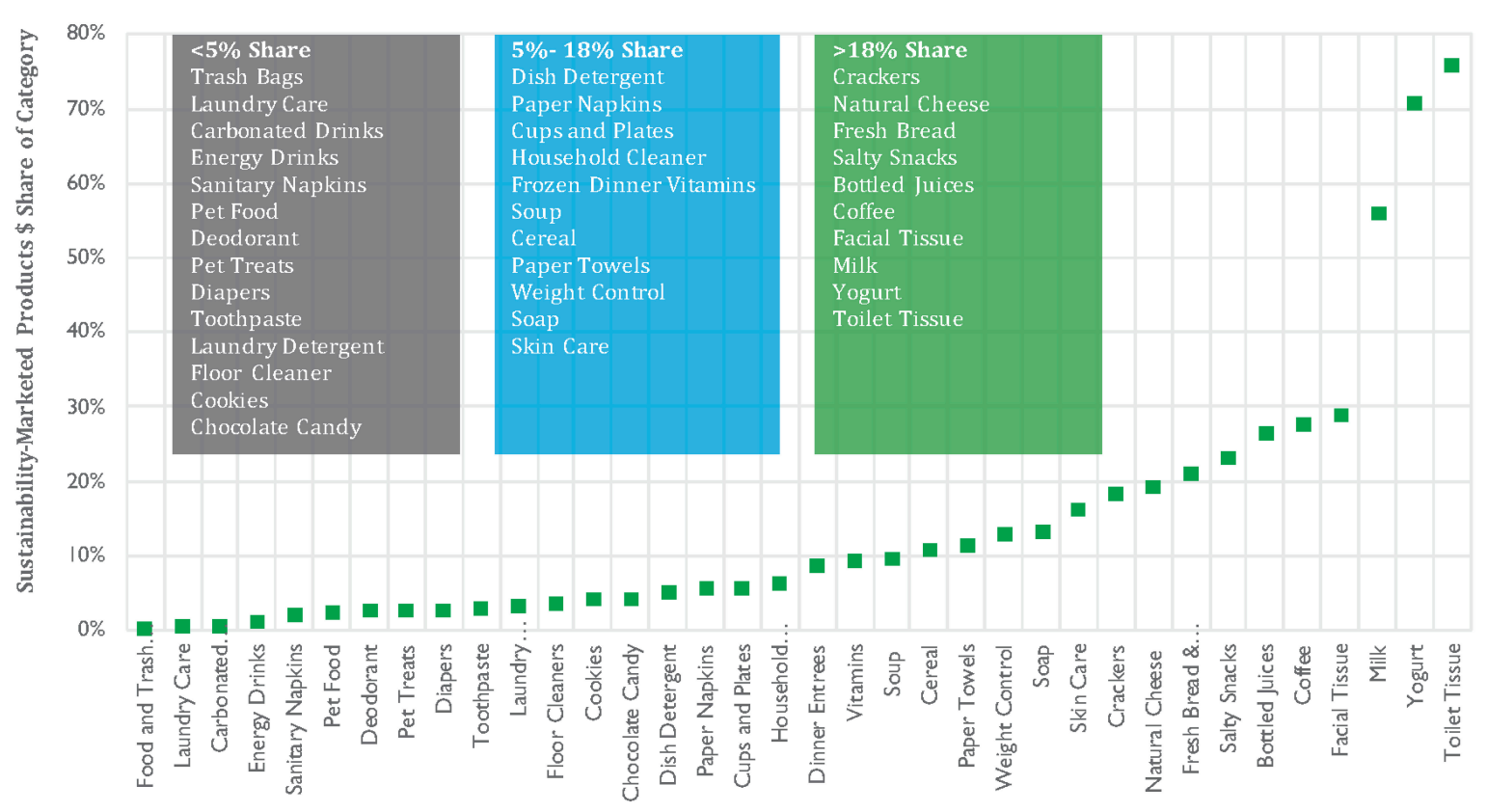

Figure 4. Sustainability-marketed products as a percentage of the category.

Based on a detailed analysis of one product category-laundry detergent-sustainability claims for functional products worked best when accompanied by functional performance claims. Brands that had a front panel claim of functional performance and sustainability delivered $64 \%$ of the growth versus $36 \%$ of products that had only sustainability claims.

\section{Comparing Sustainability Messaging Claims}

Dominant sustainability messaging claims were unique across the five CPG categories that we selected for further analysis representing categories with both low (chocolate, laundry detergent, and sanitary products) and high (yogurt, and coffee), shares of sustainability-marketed products (Table 2). Across these five categories, the most common claim was organic. About half of the claims in the five categories were exclusions such as no growth hormones.

Regarding the three low share categories: laundry detergent products featured a plant-based claim in $90 \%$ of the sustainability-marketed dollar sales (but declined in growth) (Table 2). Sanitary products often claimed to be organic and dye-free appearing in roughly two thirds of share. This category was also disrupted by an innovation that is perceived as a sustainability innovation (the re-useable menstrual cup), which contributed to some of the growth. In chocolate, the Rainforest Alliance 
certification appeared on $75 \%$ of sales and non-GMO was second with $18 \%$ share of sales. Regarding the two high-share categories: $62 \%$ of the sustainability-marketed dollar sales in yogurt featured the claim non-GMO and organic. In coffee, sustainably sourced appeared on packages for $55 \%$ of sales and Fair Trade second with a 31\% share of sales. Share of sustainability-marketed product category growth varied widely and not always in line with the dollar sales share (Table 2).

Table 2. Dollar sales volume and growth associated with top sustainability marketing messages.

\begin{tabular}{|c|c|c|c|}
\hline Claim & $\begin{array}{l}\text { Share of average annual dollar } \\
\text { sales of sustainability-marketed } \\
\text { products }\end{array}$ & $\begin{array}{l}\text { Share of } 2013-2018 \text { growth } \\
\text { of sustainability-marketed } \\
\text { products }\end{array}$ & $\begin{array}{l}\text { Number of products } \\
\text { (multiple messages per } \\
\text { product; bold for category) }\end{array}$ \\
\hline Yogurt & & & 342 \\
\hline Non-GMO & $62 \%$ & $53 \%$ & 199 \\
\hline Organic & $44 \%$ & $6 \%$ & 140 \\
\hline Grass-fed & $25 \%$ & $19 \%$ & 80 \\
\hline No growth hormones & $17 \%$ & $45 \%$ & 54 \\
\hline B-corporation & $12 \%$ & $3 \%$ & 39 \\
\hline Vegan & $3 \%$ & $9 \%$ & 11 \\
\hline Coffee & & & 484 \\
\hline Sustainably sourced & $55 \%$ & $89 \%$ & 61 \\
\hline Fair Trade & $31 \%$ & $6 \%$ & 210 \\
\hline Organic & $15 \%$ & $25 \%$ & 333 \\
\hline Rainforest Alliance & $4 \%$ & $-7 \%$ & 16 \\
\hline Chocolate & & & 513 \\
\hline Rainforest Alliance & $75 \%$ & $41 \%$ & 87 \\
\hline Non-GMO & $18 \%$ & $70 \%$ & 298 \\
\hline Fair trade & $16 \%$ & $34 \%$ & 240 \\
\hline Organic & $14 \%$ & $27 \%$ & 303 \\
\hline Vegan & $7 \%$ & $14 \%$ & 130 \\
\hline B-corporation & $1 \%$ & $1 \%$ & 49 \\
\hline Laundry detergent & & & 111 \\
\hline Plant-based & $90 \%$ & $-21 \%$ & 49 \\
\hline EPA safer choice seal & $37 \%$ & $7 \%$ & 21 \\
\hline No animal testing & $14 \%$ & $-2 \%$ & 4 \\
\hline Paraben free & $5 \%$ & $3 \%$ & 11 \\
\hline Biodegradable & $2 \%$ & $-1 \%$ & 7 \\
\hline B-corporation & $1 \%$ & $1 \%$ & 7 \\
\hline Sanitary products & & & 14 \\
\hline Organic & $63 \%$ & $69 \%$ & 11 \\
\hline Dye free & $62 \%$ & $73 \%$ & 7 \\
\hline Chlorine free & $53 \%$ & $61 \%$ & 7 \\
\hline Eco-friendly & $33 \%$ & $28 \%$ & 1 \\
\hline No pesticides & $27 \%$ & $45 \%$ & 3 \\
\hline
\end{tabular}

Claims with less than $1 \%$ dollar sales were omitted. Share of growth with negative sign declined over the period. Individual products may have one or more claims. 


\section{Growth of Sustainability-Marketed Products by Category}

In terms of category growth from 2013 to 2018, most of the CPG market (33 of the 36 categories) outperformed conventionally-marketed products (Figure 5). The top performers with growth rates of over $100 \%$ over the five-year period (in descending order from greatest growth) included: sanitary products, laundry care, diapers, carbonated beverages, deodorant, toothpaste, frozen dinner entrees, cookies, and soup.

The three categories that did not experience share growth (toilet tissue, cups and plates, paper napkins) had high private label (retailer brands) shares. As mentioned in methods, private label was classified as conventionally-marketed by default because we couldn't isolate the sustainability-marketed characteristics in our dataset, with the exception of some disaggregated organic food private label products.

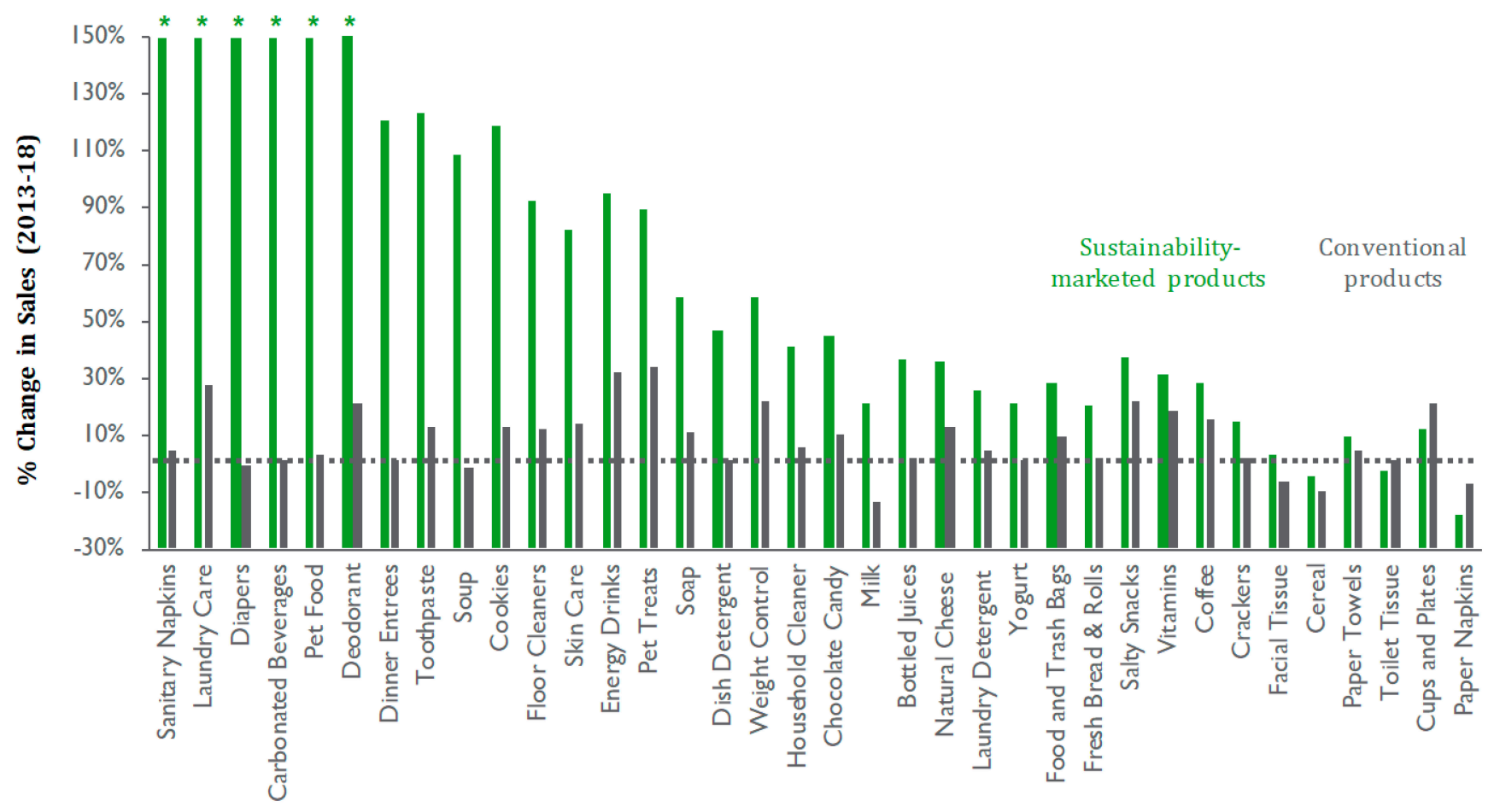

Figure 5. For over $90 \%$ of individual product categories in the CPG market, the growth of sustainabilitymarketed products outpaced the growth of their respective categories. ${ }^{*}$ Note: Actual sales growth for sustainability-marketed products in these categories from 2013 to 2018 were $1906 \%, 478 \%$, 247\%, 187\%, $162 \%$, and $150 \%$, respectively.

\section{The Role of Third-Party Certifications and New-Product Growth}

We found that third-party certifications held a surprisingly large share of the category growth compared to products with no certified sustainability claims across both high and low share categories (Table 3). Products with third-party certifications accounted for $88-99 \%$ of the overall growth of sustainability-marketed products between 2013 and 2018. Yogurt was an outlier because third-party certification only made up 
$46 \%$ of the growth. Many yogurt packages contained both certified and non-certified claims.

Table 3. Growth of third-party certified sustainability-marketed products, and new products as percent of sustainable growth.

\begin{tabular}{|c|c|c|c|c|c|}
\hline Result & Coffee & Chocolate & Laundry Detergent & Sanitary Napkins & Yogurt \\
\hline 2018 Total Category Sales (billions) & $\$ 9.8 \mathrm{~B}$ & $\$ 14 \mathrm{~B}$ & $\$ 7.4 \mathrm{~B}$ & $\$ 2.8 \mathrm{~B}$ & $\$ 7.1 \mathrm{~B}$ \\
\hline $\begin{array}{l}\text { Third-party certified sustainability-marketed } \\
\text { products as a \% of sustainable growth }\end{array}$ & $99.9 \%$ & $88 \%$ & $90 \%$ & $94 \%$ & $46 \%$ \\
\hline $\begin{array}{l}\text { Non-certified sustainability-marketed products } \\
\text { as \% of sustainable growth }\end{array}$ & $0.03 \%$ & $12 \%$ & $10 \%$ & $6 \%$ & $54 \%$ \\
\hline $\begin{array}{l}P \text { values for a one sample proportion test with } \\
\text { null hypothesis } 0.5\end{array}$ & 0.000 & 0.000 & 0.000 & 0.002 & 0.134 \\
\hline
\end{tabular}

Claims with less than $1 \%$ dollar sales were omitted.

\section{The Role of Legacy Brands}

Large, legacy brands were largely responsible for scaling the growth of sustainability-marketed products in both low and high share categories (sanitary products being the outlier because non-legacy brands disrupted the market). These legacy brands often dominated in terms of dollar sales (i.e., they took up a substantial share with $40-80 \%$ of the sustainabilitymarketed category) though not in share of products (Table 4). In coffee, for example, legacy brands accounted for $83 \%$ of dollar sales of sustainabilitymarketed products but only $15 \%$ of the products. While there were many small brands with sustainability claims, two large brands enjoyed a large portion of the dollar market share of sustainability-marketed coffee.

Table 4. Share of legacy brands per category within sustainability-marketed products.

\begin{tabular}{lccc}
\hline $\begin{array}{l}\text { Category (Total number of } \\
\text { products in parentheses) }\end{array}$ & $\begin{array}{l}\text { Share of legacy brands average } \\
\text { annual dollar sales of } \\
\text { sustainability-marketed products }\end{array}$ & $\begin{array}{l}\text { Share of legacy brands } \\
\text { products of sustainability- } \\
\text { marketed products (n) }\end{array}$ & $\begin{array}{l}\text { Share of sustainability- } \\
\text { marketed products of } \\
\text { total category }\end{array}$ \\
\hline Yogurt (342) & $75 \%^{* *}$ & $40 \% *(138)$ & $71 \%^{* *}$ \\
Coffee (484) & $83 \%^{* *}$ & $15 \%^{* *}(74)$ & $28 \%^{* *}$ \\
\hline Chocolate (513) & $44 \%^{*}$ & $2 \%^{* *}(11)$ & $4 \%^{* *}$ \\
Laundry detergent (111) & $46 \%$ & $15 \%^{* *}(17)$ & $3 \%^{* *}$ \\
Sanitary napkins (14) & $18 \%^{*}$ & $21 \%(3)$ & $2 \% * *$ \\
\hline
\end{tabular}

Claims with less than $1 \%$ dollar sales were omitted. $P$-values for a one sample proportion test with a normal approximation and null hypothesis 0.5 : ** $<0.01 ; *<0.05$.

\section{DISCUSSION}

\section{The Association between Sustainability Messages and Product Sales Growth}

There is a continued debate about whether sustainability messages matter to consumers. This research shows that sustainability-marketed 
products already comprise a substantial segment of the US CPG market. It is still a relatively modest share, but far above the $4 \%$ number cited by the UNEP global analysis in 2005 or the "abysmally low" market share referenced by a study from 2010 [30].

This research can serve as reference points for future research that investigates the behavior-intention gap or perceptions of sustainability messages. Our findings suggest that the concept of an "ever present and widely acknowledged gap" [8] between sustainability intent and purchasing may need to be revisited in light of the recent growth of sustainability-marketed products. We are not suggesting that the gap has been eliminated, but there is far more variation in the gap than previous research suggests.

\section{Marketing Messages that Seem to Drive Growth of Sustainability- Marketed Products}

Previous research has shown that consumers perceived a trade-off between functional performance and sustainable attributes, and may question the efficacy of sustainable products with high functional requirements $[15,23,24]$. Indeed, our work agrees with those findings because high-functional categories generally had lower market share of sustainability-marketed products compared to low-functional categories. In the analysis about messaging in the laundry detergent category, we showed that companies can likely attenuate the perceived negative perceptions of sustainability claims on functional products by including explicit cues about a product's strength or efficacy, which agrees with previous research [15].

On-pack messaging in CPG is challenging as products must also market core product attributes in their limited space. Consequently, most marketing claims in our findings were limited to succinctly expressed claims, as well as certification labels, such as organic. Organic and non$G M O$ were the most dominant messages across food categories. In addition, each category had additional sustainability claims and certifications that were most appropriate for that category. For example, plant-based for laundry, Rainforest Alliance for chocolate, sustainably sourced in coffee, and Non-GMO for yogurt. These findings provide some empirical evidence to support prior research suggesting that ethical product messages work best when the type of claim is aligned with the product category [17].

Products with third-party certifications accounted for an outsized share of growth delivered by sustainable-marketing messages. In four of the five categories we examined, third-party certifications accounted for over $85 \%$ of the share of sustainability-marketed product growth. We believe this finding is particularly notable given that obtaining a thirdparty certification often incurs an external cost (often a recurring fee), in addition to the internal costs required to meet such certifications (e.g., auditing ingredients, supply chains, and production processes). These 
findings may inform future research analyzing the costs and benefits of third-party certifications.

Our results also described large variances in category market share that often correlated with the actions of large, legacy brands. In a product category such as yogurt, legacy brands have brought sustainability marketing to their core product lines, and sustainability-marketed products have obtained a very large portion of the market share (71\%). In many other categories, where legacy brands have not brought sustainability marketing to core products, the market share remained below $10 \%$. Smaller, more nimble brands can bring innovation to a category, but without large market share, we do not see massive uptake in the same way as in yogurt (i.e., Dannon), and coffee (i.e., Starbucks). This suggests that retailers, marketers, and consumers who want to support the sustainability agenda could make a considerable impact on the overall market by working to influence these large, legacy brands who may be reluctant to risk losing share of their already successful products.

\section{Limitations and Future Research}

Limitations of the research design. Large-scale, barcoded scanner data describes one aspect of consumer behavior. Researchers have also examined consumer behavior in controlled or experimental studies, which is a valuable, and complementary, research design. We did not investigate consumer behavior in terms of product evaluation and resulting purchases. We employed predominantly descriptive methods. The findings and causal linkages relied on prior research or marketresearch knowledge. We acknowledged this limitation by pointing out that messages and sales were merely associated. Other explanations beyond ours are conceivable. We did build a comprehensive case on why we argue that sustainability messages are driving product sales growth.

We found it likely that the simplest explanation is the most appropriate: sustainability-marketed products are seeing outsized growth, in part, because customers are putting their dollars behind their beliefs. It is even possible that we are at a tipping point. Sustainable products that held low market share are rapidly gaining share as companies learn how to market these products, and consumers learn more about the effects of unsustainable consumption. We also may be seeing a tipping point in sustainable consumption.

Limitations of statistical nature. We coded the products within our scope (36 categories). These in-sample results were extrapolated to the total US market. The category sampling error implies that these figures were bound by statistical uncertainty, which we have quantified. We are confident that an analysis of all categories would be similar to our results because the category sampling attempts to be representative. Related limitations concern the internal validity of the research design. They include a possible measurement error following the definition of what sustainable products are (which we addressed in the method section, e.g., 
claims were not validated), coding accuracy (a long process that might be prone to errors), and that codes were not propagated backwards in time (but are arguably conservative).

The conclusions were derived from CPG products sold in a particular context, market, and time. Inferences that go beyond the US market ought to consider those circumstances. Finally, we should note that consumers may choose to buy sustainable products for many reasons. People may decide to buy a sustainability-marketed product, especially food and drinks, because they believe it is healthier and not for sustainability reasons, i.e., environmental, social, or governance, reasons. Continued research is needed to understand what motivates people and why sustainability-marketed products are seeing such high growth across most categories.

\section{CONCLUSIONS}

Researchers, marketers, and retailers all play a critical role in ensuring the long-term viability of humanity and our planet. This research suggests that companies that invest in sustainable offerings can benefit both the planet and top-line sales. Practitioners should recognize that sustainability-marketed products at $16.6 \%$ share of market were associated with over half of the CPG growth from 2013 to 2018. This figure stands out because CPG growth was just over $1 \%$ over the same time period. We saw share growth in over $90 \%$ of the categories examined. We believe that firms should continue to invest in this growth area and experiment with messaging that communicate their sustainability efforts to drive additional share increases and reduce the gap between intentionality and behavior. The findings from food categories that were losing share suggest that turning to marketing sustainable attributes could be an effective strategy to counter overall category decline. In functional categories, our research suggests that combining functional performance and sustainability messages could be an opportunity to drive sales. Another finding suggests that companies and researchers should analyze the returns on third-party certifications as they were associated with a large portion of the growth of sustainability-marketed products, which would suggest a worthy investment. Finally, legacy brands may have the potential to move entire categories by committing to sustainability and communicating this on pack.

While core product attributes remain critical to the marketing message, sustainability claims can update a product and make it more attractive to today's consumer. Not contemplating this sustainability growth from a brand or retailer perspective can create an opportunity for a competitor to upend the category. Research has made clear that people need to dramatically alter consumption patterns in coming years to avoid catastrophic environmental damage. Businesses have a key role to play. We hope practitioners will use these findings to build the case to further invest in sustainable products. 


\section{DATA AVAILABILITY}

The dataset from the study is not available because the dataset used for analysis is the property of Information Resources Inc. All estimates and analyses in this paper based on Information Resources, Inc. data are by the author and not by Information Resources, Inc.

\section{AUTHOR CONTRIBUTIONS}

RKS designed the study with input from TVH, UA, and TW. RKS, UA, TVH and TW analyzed the data. TVH, RKS, and UA wrote the paper with input from all authors.

\section{CONFLICTS OF INTEREST}

Tensie Whelan served as President of Rainforest Alliance from 2000 to 2015. Rainforest Alliance-certified is one of the certification claims found in certain CPG categories and reviewed by the authors. The other authors declare that there is no conflict of interest.

\section{ACKNOWLEDGMENTS}

We would like to acknowledge the research support of NYU interns Samuel Wallace, Jessica Tou, Anirudh Dave, Ethan Ou, and Patrick Wu.

We would like to thank the IRI organization for the generous donation of its data. The authors are grateful for the support and inspiration of IRI's Larry Levin, Robert Tomei, Jeanne Livelsberger and Sheila Noojibail.

\section{REFERENCES}

1. Whiteman G, Walker B, Perego P. Planetary Boundaries: Ecological Foundations for Corporate Sustainability. J Manag Stud. 2013;50(2):307-36.

2. Rockström J, Sachs J, Öhman M, Schmidt-Traub G. Sustainable Development and Planetary Boundaries. Sustainable Development Solutions Network Report for the UN High-Level Panel of Eminent Persons on the Post-2015 Development Agenda. New York (NY, US): SDSN; 2013.

3. Svensson G, Wagner B. Business sustainability and E-footprints on Earth's life and ecosystems: Generic models. Eur Bus Rev. 2012;24(6):543-52.

4. White K, Habib R, Hardisty DJ. How to SHIFT Consumer Behaviors to be More Sustainable: A Literature Review and Guiding Framework. J Mark. 2019;83(3):22-49.

5. Trudel R, Cotte J. Does it Pay to Be Good? MIT Sloan Management Review. 2009;50:61-8.

6. Carrington MJ, Neville BA, Whitwell GJ. Lost in translation: Exploring the ethical consumer intention-behavior gap. J Bus Res. 2014;67(1):2759-67.

7. Auger P, Devinney TM. Do what consumers say matter? The misalignment of preferences with unconstrained ethical intentions. J Bus Ethics. 2007;76(4):361-83.

8. Prothero A, Dobscha S, Freund J, Kilbourne WE, Luchs MG, Ozanne LK, et al. Sustainable Consumption: Opportunities for Consumer Research and Public 
Policy. J Public Policy Mark. 2011;30(1):31-8.

9. Phipps M, Ozanne LK, Luchs MG, Subrahmanyan S, Kapitan S, Catlin JR, et al. Understanding the inherent complexity of sustainable consumption: A social cognitive framework. J Bus Res. 2013;66(8):1227-34.

10. Johnstone ML, Tan LP. Exploring the Gap Between Consumers' Green Rhetoric and Purchasing Behaviour. J Bus Ethics. 2015;132(2):311-28.

11. Young W, Hwang K, McDonald S, Oates CJ. Sustainable consumption: Green consumer behaviour when purchasing products. Sustain Dev. 2010;18(1):2031.

12. Mai R, Hoffmann S, Lasarov W, Buhs A. Ethical Products = Less Strong: How Explicit and Implicit Reliance on the Lay Theory Affects Consumption Behaviors. J Bus Ethics. 2019;158(3):659-77.

13. Americans are Increasingly "Alarmed" About Global Warming-Yale Program on Climate Change Communication. Available from: https://climatecommunication.yale.edu/publications/americans-areincreasingly-alarmed-about-global-warming/. Accessed 2020 Feb 9.

14. A 'Natural' Rise in Sustainability Around the World-Nielsen. Available from: https://www.nielsen.com/eu/en/insights/article/2019/a-natural-rise-insustainability-around-the-world/. Accessed 2020 Feb 9.

15. Luchs MG, Kumar M. "Yes, but this Other One Looks Better/Works Better”: How do Consumers Respond to Trade-offs Between Sustainability and Other Valued Attributes? J Bus Ethics. 2017;140(3):567-84.

16. Luchs MG, Naylor RW, Irwin JR, Raghunathan R. The Sustainability Liability: Potential Negative Effects of Ethicality on Product Preference. J Mark. 2010;74(5):18-31.

17. Bodur HO, Gao T, Grohmann B. The Ethical Attribute Stigma: Understanding When Ethical Attributes Improve Consumer Responses to Product Evaluations. J Bus Ethics. 2014;122(1):167-77.

18. Shang J, Peloza J. Can "Real" Men Consume Ethically? How Ethical Consumption Leads to Unintended Observer Inference. J Bus Ethics. 2016;139(1):129-45.

19. Peloza J, White K, Shang J. Good and Guilt-Free: The Role of SelfAccountability in Influencing Preferences for Products with Ethical Attributes. J Mark. 2013;77(1):104-19.

20. Friberg R, Sanctuary M. Market stealing and market expansion: an examination of product introductions in the organic coffee market. Environ Econ Policy Stud. 2018;20:287-303.

21. United Nations Environment Programme. Talk the Walk: Advancing Sustainable Lifestyles Through Marketing and Communications. New York (US): United Nations Global Compact and Utopies; 2005.

22. Annunziata A, Ianuario S, Pascale P. Consumers' attitudes toward labelling of ethical products: The case of organic and fair trade products. J Food Prod Mark. 2011;17(5):518-35.

23. Newman GE, Gorlin M, Dhar R. When Going Green Backfires: How Firm Intentions Shape the Evaluation of Socially Beneficial Product Enhancements. J Consum Res. 2014;41(3):823-39. 
24. Lin Y-C, Chang CA. Double Standard: The Role of Environmental Consciousness in Green Product Usage. J Mark. 2012;76(5):125-34.

25. Darnall N, Ji H, Vázquez-Brust DA. Third-Party Certification, Sponsorship, and Consumers’ Ecolabel Use. J Bus Ethics. 2018;150(4):953-69.

26. Grunert KG, Hieke S, Wills J. Sustainability labels on food products: Consumer motivation, understanding and use. Food Policy. 2014;44:177-89.

27. Park CW, Lessig VP. Familiarity and Its Impact on Consumer Decision Biases and Heuristics. J Consum Res. 1981;8(2):223.

28. Hoyer WD, Brown SP. Effects of Brand Awareness on Choice for a Common, Repeat-Purchase Product. J Consum Res. 1990;17(2):141.

29. Wood S, Robinson S, Poor M. The efficacy of green package cues for mainstream versus niche brands: How mainstream green brands can suffer at the shelf. J Advert Res. 2018;58(2):165-76.

30. Eckhardt GM, Belk R, Devinney TM. Why don’t consumers consume ethically? J Consum Behav. 2010;9(6):426-36.

How to cite this article:

Kronthal-Sacco R, Van Holt T, Atz U, Whelan T. Sustainable Purchasing Patterns and Consumer Responsiveness to Sustainability Marketing Messages. J Sustain Res. 2020;2(2):e200016. https://doi.org/10.20900/jsr20200016 